\title{
Novel Indomethacin Action: Selective and Direct Activation of Protein Kinase C- $\varepsilon$
}

\author{
Takeshi Kanno $^{1}$ Ayako Tsuchiya ${ }^{1}$ Tadashi Shimizu² Akito Tanaka $^{2}$ \\ Tomoyuki Nishizaki ${ }^{1,2}$ \\ 1Division of Bioinformation, Department of Physiology, Hyogo College of Medicine, 1-1 Mukogawa- \\ cho, Nishinomiya 663-8501, Japan; ${ }^{2}$ Laboratory of Chemical Biology, Advanced Medicinal Research \\ Center, Hyogo University of Health Sciences, 1-3-6 Minatojima, Chuo-ku, Kobe 650-8530, Japan
}

\author{
Key Words \\ Indomethacin $\bullet$ Protein kinase $\mathrm{C}-\varepsilon \cdot$ Selective activation $\bullet$ Direct binding
}

\begin{abstract}
Background/Aims: In our earlier study, indomethacin potentiated $\alpha 7$ acetylcholine (ACh) receptor responses by activating protein kinase $C$ (PKC). The present study was conducted to gain further insight into the indomethacin action on PKC. Methods: PKC activity was assayed in PC-12 cells or under the cell-free conditions. PKC- $\varepsilon$ was knocked-down using the siRNA to silence the PKC- $\varepsilon$-targeted gene. A fluorescein-conjugated indomethacin was synthesized to examine the interaction of indomethacin with PKC- $\varepsilon$. Results: In the in situ PKC assay, indomethacin activated PKC in PC-12 cells in a concentration (1-100 $\mu \mathrm{M})$-dependent manner, and the activation was suppressed by knocking-down PKC- $\varepsilon$. In the cell-free PKC assay, indomethacin $(100 \mu \mathrm{M})$ activated PKC- $\varepsilon$ in the absence of diacylglycerol, phosphatidylserine, and calcium, but other PKC isozymes such as $\alpha, \beta \mathrm{I}, \beta \mathrm{II}, \gamma, \delta, 1$, and $\zeta$ were not activated. In the indomethacin binding assay using a fluorescent-conjugated indomethacin on blue nativepolyacrylamide gel electrophoresis (blue native-PAGE), a fluorescent signal was detected at the site consistent with PKC- $\varepsilon$ protein and the signal was attenuated by adding non-conjugated indomethacin or eliminated by pretreatment with non-conjugated indomethacin. Conclusion: The results of the present study show that indomethacin has the potential to selectively activate PKC- $\varepsilon$ through its direct binding, independently of cyclooxygenase (COX) inhibition.
\end{abstract}

Copyright $(2012$ S. Karger AG, Basel

\section{Introduction}

Indomethacin is an inhibitor of COX-1 and - 2 and exerts its anti-inflammatory action [14]. We have found that indomethacin stimulates presynaptic glutamate release and facilitates 
hippocampal synaptic transmission in a $\mathrm{Ca}^{2+} /$ calmodulin-dependent protein kinase II (CaMKII)-dependent manner, possibly responsible for improvement of learning and memory impairment or enhancement in learning and memory potentials for normal rats and healthy humans [5]. This suggests that indomethacin serves as a CaMKII activator. Surprisingly, indomethacin did not activate CaMKII under the cell-free conditions (unpublished data), indicating indirect CaMKII activation by indomethacin. CaMKII is activated by $\mathrm{Ca}^{2+} / \mathrm{calmodul}$ binding and the ensuing autophosphorylation, but activated CaMKII is otherwise inactivated by protein phosphatase 1 (PP1)-mediated dephosphorylation of phosphorylated CaMKII. Inhibition of PP1 activity, therefore, could cause a persistent CaMKII activation. Expectedly, we have obtained the data that indomethacin suppresses PP1 activity (unpublished data).

In addition to the indomethacin action on CaMKII/PP1, indomethacin potentiates $\alpha 7$ $\mathrm{ACh}$ receptor responses and facilitates hippocampal synaptic transmission by activating PKC, possibly PKC- $\varepsilon$ [6]. No direct evidence for indomethacin-induced PKC- $\varepsilon$ activation, however, has been provided. To address this point, we assayed PKC activity in PC-12 cells or under the cell-free conditions, knocked-down PKC- $\varepsilon$ using the siRNA, and synthesized a fluorescein-conjugated indomethacin. We show here that indomethacin serves as a selective $\mathrm{PKC}-\varepsilon$ activator through its direct binding.

\section{Materials and Methods}

\section{Cell culture}

Rat PC-12 cells, that were obtained from RIKEN Cell Bank (Tsukuba, Japan), were cultured in Dulbecco's modified Eagle's medium supplemented with $10 \%$ (v/v) heat-inactivated fetal bovine serum, $10 \%(\mathrm{v} /$ v) heat-inactivated horse serum, penicillin $(100 \mathrm{U} / \mathrm{ml})$, and streptomycin $(0.1 \mathrm{mg} / \mathrm{ml})$ in a humidified atmosphere of $5 \% \mathrm{CO}_{2}$ and $95 \%$ air at $37{ }^{\circ} \mathrm{C}$. Experiments were performed in PC- 12 cells differentiated by treatment with nerve growth factor $(100 \mathrm{ng} / \mathrm{ml})$ for 5 days.

\section{In situ PKC assay}

PKC activity in rat PC-12 cells was assayed by the method as previously described [7]. Cells were treated with indomethacin at $37^{\circ} \mathrm{C}$ for $10 \mathrm{~min}$ in an extracellular solution $\left[137 \mathrm{mM} \mathrm{NaCl}, 5.4 \mathrm{mM} \mathrm{KCl}, 10 \mathrm{mM} \mathrm{MgCl} \mathrm{z}^{\prime}\right.$ $5 \mathrm{mM}$ ethylene glycol-bis(2-aminoethyl ether)-N,N,N', $\mathrm{N}^{\prime}$-tetraacetic acid, $0.3 \mathrm{mM} \mathrm{Na}_{2} \mathrm{HPO}_{4^{\prime}} 0.4 \mathrm{mM} \mathrm{K}_{2} \mathrm{HPO}_{4^{\prime}}$ and $20 \mathrm{mM}$ 4-(2-hydroxyethyl)-1-piperazine-ethanesulfonic acid, $\mathrm{pH}$ 7.2]. Then, cells were rinsed with 100 $\mu \mathrm{l} \mathrm{of} \mathrm{Ca}^{2+}$-free phosphate-buffered saline (PBS) and incubated at $30^{\circ} \mathrm{C}$ for $15 \mathrm{~min}$ in $50 \mu \mathrm{l}$ of the extracellular solution containing $50 \mu \mathrm{g} / \mathrm{ml}$ digitonin, $25 \mathrm{mM}$ glycerol 2-phosphate, $200 \mu \mathrm{M}$ ATP, and $100 \mu \mathrm{M}$ synthetic PKC substrate peptide (Pyr-Lys-Arg-Pro-Ser-Gln-Arg-Ser-Lys-Tyr-Leu)(Peptide Institute Inc., Osaka, Japan). The supernatants were collected and boiled at $100{ }^{\circ} \mathrm{C}$ for $5 \mathrm{~min}$ to terminate the reaction. Aliquot of the solution $(20 \mu \mathrm{l})$ was loaded onto a reversed phase high performance liquid chromatography (HPLC) (LC10ATvp, Shimadzu Co., Kyoto, Japan). A substrate peptide peak and a new product peak were detected at an absorbance of $214 \mathrm{~nm}$ (SPD-10Avp UV-VIS detector, Shimadzu Co., Kyoto, Japan). It was confirmed that each peak corresponds to non-phosphorylated and phosphorylated substrate peptide in the analysis of matrixassisted laser desorption ionization time of flight mass spectrometry (Voyager DE-STR, PE Biosystems Inc., Foster City, USA). Molecular weights were calibrated from the two standard spectrums, bradykinin (MW 1060.2) and neurotensin (MW 1672.9). Areas for non-phosphorylated and phosphorylated PKC substrate peptide were measured (total area corresponds to concentration of PKC substrate peptide used here), and the amount of phosphorylated substrate peptide was calculated. Phosphorylated substrate peptide (pmol/1 $\mathrm{min} /$ cell protein weight) was used as an index of PKC activity.

Knocking-down $P K C$ - $\varepsilon$

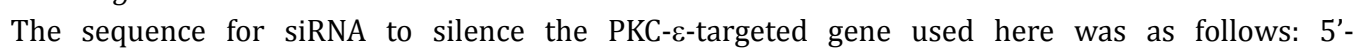
CACAUCAGUGACGAACUCAUTT-3' and 5'-AUGAGUUCGUCACUGAUGUGTT-3'. The siRNA containing scrambled sequences with the GC content and nucleic acid composition same as those for the PKC- $\varepsilon$ siRNA was used 
as a negative control (NC) siRNA. PC-12 cells were transfected with the PKC- $\varepsilon$ siRNA or the NC siRNA using a Lipofectamine reagent (Invitrogen, Carlsbad, CA, USA), and $48 \mathrm{~h}$ later after transfection in situ PKC assay was carried out.

\section{Western blotting}

PC-12 cells transfected with the PKC- $\varepsilon$ siRNA or the NC siRNA were homogenized with a sonicator in an ice-cold PBS containing $1 \%(\mathrm{v} / \mathrm{v}$ ) protease inhibitor cocktail (Nacalai, Kyoto, Japan), and then centrifuged at 3,000 rpm for $5 \mathrm{~min}$ at $4{ }^{\circ} \mathrm{C}$. The supernatants $(20 \mu \mathrm{g}$ of protein) were loaded on $10 \%(\mathrm{w} / \mathrm{v})$ acrylamide gel and electrophoresed. Separated proteins were transferred onto polyvinylidene difluoride membrane. Blotting membranes were blocked with TBS-T (150 mM NaCl, 0.1\% Tween20 and $20 \mathrm{mM}$ Tris, pH 7.5) containing $5 \%(\mathrm{w} / \mathrm{v})$ bovine serum albumin (Wako, Osaka, Japan) and reacted with an anti-PKC- $\varepsilon$ antibody (BD Biosciences, San Jose, CA, USA) or an anti- $\beta$-actin antibody (Sigma, St. Louis, MO, USA), followed by a horseradish peroxidase-conjugated goat anti-mouse IgG antibody. Immunoreactivity was detected with an ECL kit (GE Healthcare, Piscataway, NJ, USA) and visualized using a chemiluminescence detection system (GE Healthcare).

\section{Cell-free PKC assay}

PKC activity in the cell-free systems was quantified by the method as previously described [7]. Briefly, synthetic PKC substrate peptide $(10 \mu \mathrm{M})$ was reacted with a variety of PKC isozymes in a medium containing $20 \mathrm{mM}$ Tris-HCl (pH 7.5), $5 \mathrm{mM}$ Mg-acetate, $10 \mu \mathrm{M}$ ATP, and indomethacin in the absence of phosphatidylserine and diacylglycerol at $30{ }^{\circ} \mathrm{C}$ for $5 \mathrm{~min}$. Activity for novel PKCs such as PKC- $\delta,-\varepsilon,-\eta$, and $-\mu$ was assayed in $\mathrm{Ca}^{2+}$-free medium and activity for the other PKC isozymes in the medium containing 100 $\mu \mathrm{M} \mathrm{CaCl}$. After loading on a reversed phase HPLC (LC-10ATvp), a substrate peptide peak and a new product peak were detected at an absorbance of $214 \mathrm{~nm}$. Areas for non-phosphorylated and phosphorylated PKC substrate peptide were measured (total area corresponds to concentration of PKC substrate peptide used here), and the amount of phosphorylated substrate peptide was calculated. Phosphorylated substrate peptide (pmol/1 min) was used as an index of PKC activity.

\section{Indomethacin binding assay}

We synthesized a fluorescein-conjugated indomethacin. PKC- $\varepsilon$ was separated by blue native polyacrylamide gel electrophoresis. Briefly, PKC- $\varepsilon$ protein was dissolved in a sample buffer [50 mM immidazole, $50 \mathrm{mM} \mathrm{NaCl}, 5 \mathrm{mM}$ 6-aminohexanoic acid, 40\% (v/v) glycerol, 0.5\% (w/v) Coomassie G-250 and $1 \%(\mathrm{w} / \mathrm{v})$ digitonin, $\mathrm{pH} 7.0]$, and electrophoresed onto a TGX Gel (BioRad, Hercules, CA, USA) in a cathode buffer [50 mM Tricine, 7.5 mM imidazole, and 0.02\% (w/v) Coomassie G-250, pH 7.0] and an anode buffer (25 mM imidazole, pH 7.0). After pretreatment with or without non-conjugated indomethacin (1 mM) at $30{ }^{\circ} \mathrm{C}$ for $30 \mathrm{~min}$, gels were reacted with fluorescein-conjugated indomethacin $(1 \mathrm{mM})$ in the presence and absence of non-conjugated indomethacin $(1 \mathrm{mM})$ at $30{ }^{\circ} \mathrm{C}$ for $60 \mathrm{~min}$. Fluorescent signals were visualized using FluoroPhoreStar3000 (Anatech, Tokyo, Japan).

Statistical analysis

Statistical analysis was carried out using Dunnett's test and unpaired $t$-test.

\section{Results}

Indomethacin activates $P K C$ in $P C-12$ cells

We initially carried out in situ PKC assay using PC-12 cells. In the reversed phase HPLC profiles, indomethacin $(100 \mu \mathrm{M})$ produced a new peak, that corresponds to phosphorylated substrate peptide (Fig. 1A), and the effect was reversed by GF109203X (100 nM), a PKC inhibitor (Fig. 1A). This confirms that indomethacin activates PKC. Indomethacin activated PKC in a concentration (1-100 $\mu \mathrm{M})$-dependent manner, the extent reaching approximately 2 folds of basal levels at $100 \mu \mathrm{M}$ (Fig. 1B). 


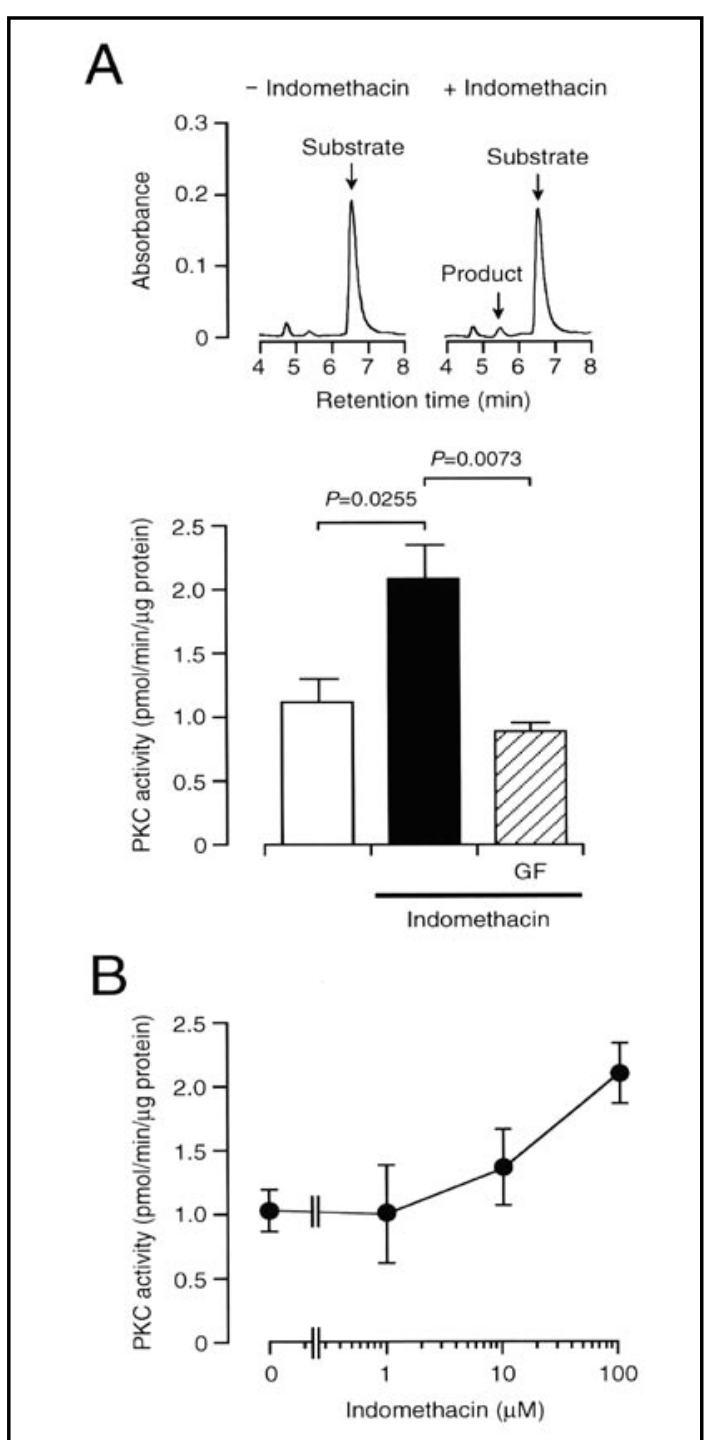

Fig. 1. Indomethacin-induced PKC activation in PC12 cells. (A) Cells were treated with indomethacin $(100 \mu \mathrm{M})$ for $10 \mathrm{~min}$ in the presence and absence of GF109203X (GF)(100 nM), and then, PKC activity was assayed. Reversed phase HPLC profiles are shown in the upper column. Note that a new peak (Product) is found after treatment with indomethacin. Substrate, substrate peptide peak. In the graph, each column represents the mean $( \pm$ SEM) PKC activity (pmol $/ \mathrm{min} / \mu$ g protein) $(\mathrm{n}=4)$. $P$ value, Dunnett's test. (B) Cells were treated with indomethacin at concentrations as indicated for 10 min, and PKC activity was assayed. In the graph, each point represents the mean $( \pm$ SEM) PKC activity $(\mathrm{pmol} / \mathrm{min} / \mu \mathrm{g}$ protein $)(\mathrm{n}=4)$.
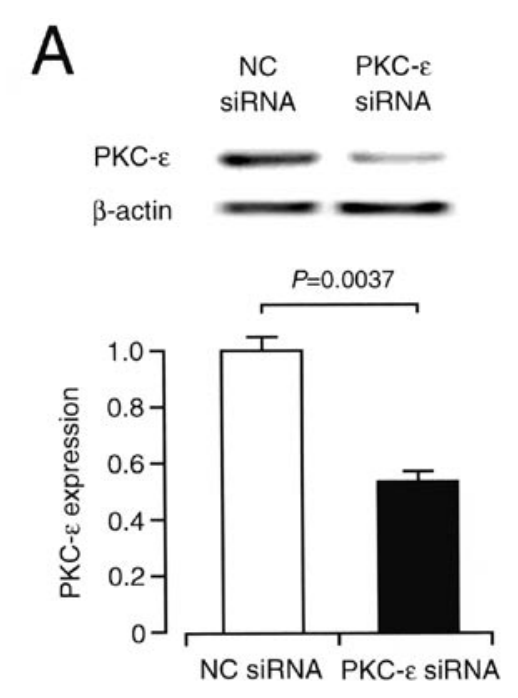

B

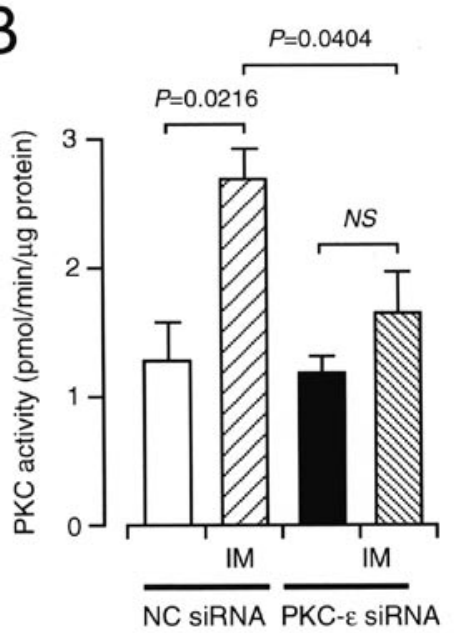

Fig. 2. Indomethacin-induced $P K C-\varepsilon$ activation in PC-12 cells. (A) PC-12 cells were transfected with the NC siRNA or the PKC- $\varepsilon$ siRNA, and $48 \mathrm{~h}$ later after transfection Western blotting was carried out. In the graph, each column represents the mean $( \pm$ SEM) intensity of PKC- $\varepsilon$ protein normalized by $\beta$-actin intensity $(\mathrm{n}=4)$. $P$ value, unpaired $t$-test. (B) Cells transfected with the NC siRNA or the PKC- $\varepsilon$ siRNA were untreated and treated with indomethacin (IM) $(100 \mu \mathrm{M})$ for $10 \mathrm{~min}$, and PKC activity was assayed. Each column represents the mean $( \pm$ SEM) PKC activity ( $\mathrm{pmol} / \mathrm{min} / \mu \mathrm{g}$ protein) $(\mathrm{n}=4) . P$ value, Dunnett's test. $N S$, not significant.

Our earlier study suggests that indomethacin activates PKC- $\varepsilon$ [6]. To obtain evidence for this, we constructed the siRNA to silence the PKC- $\varepsilon$-targeted gene. In the Western blot 
Fig. 3. Indomethacin-induced selective PKC- $\varepsilon$ activation under the cell-free conditions. In the cell-free systems, PKC activity was monitored. Activities of PKC isozymes as indicated were assayed in the presence and absence of indomethacin $(100 \mu \mathrm{M})$. In the graph, each column represents the mean ( \pm SEM) PKC activity (pmol/ $\min )(\mathrm{n}=4) .{ }^{* *} P<0.01$ as compared with each PKC isozyme activation in the absence of indomethacin, unpaired $t$-test.

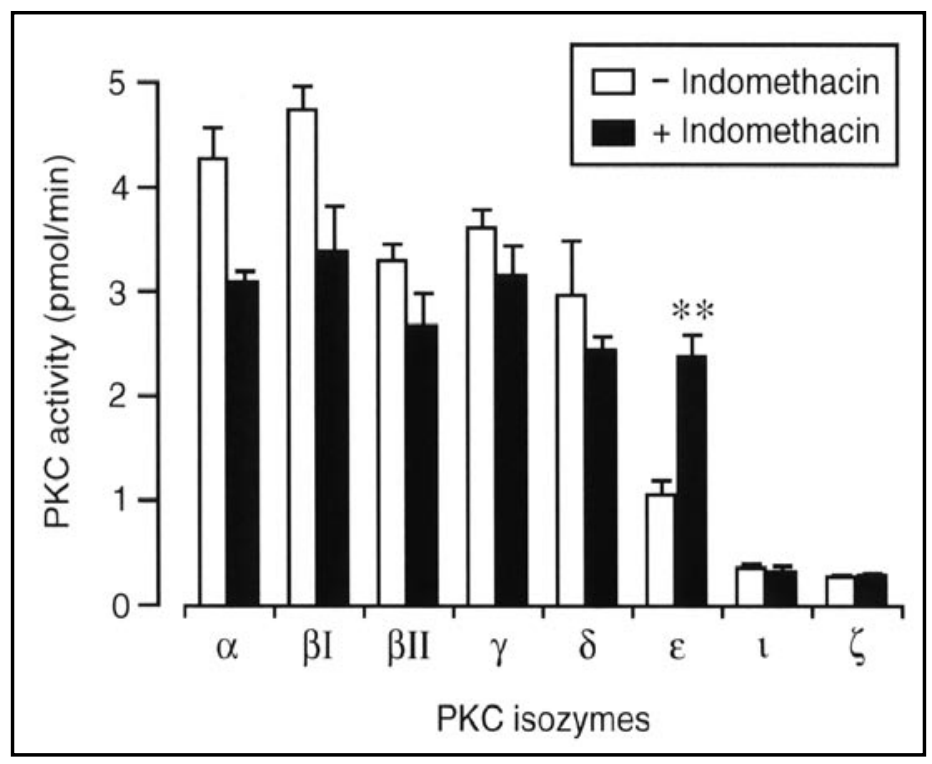

Fig. 4. Indomethacin binding to PKC- $\varepsilon$. Electrophoresed PKC- $\varepsilon$ was incubated with fluorescein-conjugated indomethacin (Flu-IM)(1 $\mathrm{mM}$ ) for $1 \mathrm{~h}$ in the absence and presence of nonconjugated indomethacin (Co-IM) (1 mM) or before and after pretreatment with non-conjugated indomethacin (Pre-IM)(1 $\mathrm{mM})$, and fluorescent signals were detected. CBB, Coomassie brilliant blue staining. Note that similar results were obtained with 4 independent experiments.

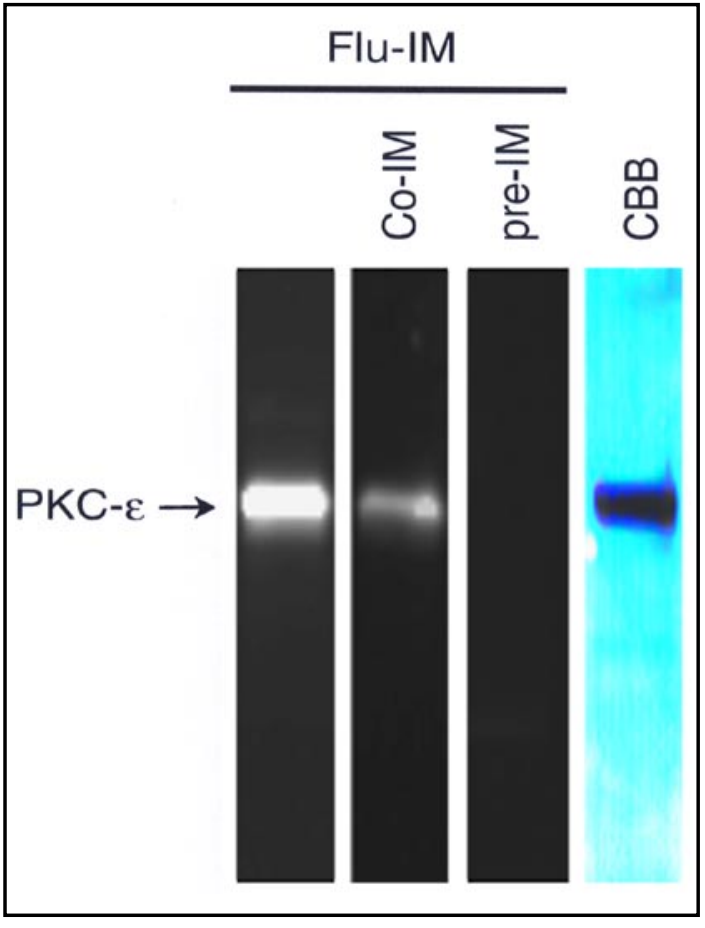

analysis, expression of the PKC- $\varepsilon$ protein for PC-12 cells transfected with the PKC- $\varepsilon$ SiRNA was significantly reduced as compared with the expression for cells transfected with the NC siRNA (Fig. 2A), indicating PKC- $\varepsilon$ knock-down. Indomethacin activated PKC for PC-12 cells transfected with the NC siRNA, but the PKC activation was significantly inhibited by knockingdown PKC- $\varepsilon$ (Fig. 2B). This accounts for preferential PKC- $\varepsilon$ activation by indomethacin.

Indomethacin directly binds to and selectively activates $P K C-\varepsilon$

To obtain further evidence for selective PKC- $\varepsilon$ activation by indomethacin, we assayed PKC in the cell-free systems. Of eight PKC isozymes examined here $(\alpha, \beta I, \beta I I, \gamma, \delta, \varepsilon, 1$, and $\zeta)$, indomethacin $(100 \mu \mathrm{M})$ activated PKC- $\varepsilon$ still in the absence of 1,2-dioleoyl-sn-glycerol, a diacylglycerol, dioleoyl-phosphatidylserine, and $\mathrm{Ca}^{2+}$ (Fig. 3A). In contrast, indomethacin $(100 \mu \mathrm{M})$ reduced activities of PKC $-\alpha,-\beta I,-\beta I I,-\gamma$, and $\delta$ or did not affect activities of PKC -1 and $-\zeta$ (Fig. 3A). It is indicated from these results that indomethacin selectively activates 
PKC- $\varepsilon$ in a diacylglycerol-, phosphatidylserine-, and $\mathrm{Ca}^{2+}$-independent manner.

In the indomethacin binding assay using a fluorescein-conjugated indomethacin, a fluorescent signal was detected at the site consistent with PKC- $\varepsilon$ protein separated on blue native-PAGE, and the signal was decreased by adding non-conjugated indomethacin or completely blocked by pretreatment with non-conjugated indomethacin (Fig. 4), indicating direct indomethacin binding to PKC- $\varepsilon$. Overall, indomethacin appears to serve as a selective activator of $\mathrm{PKC}-\varepsilon$ through its direct binding.

\section{Discussion}

PKC isozymes include conventional PKCs such as PKC- $\alpha,-\beta I,-\beta I I$, and $-\gamma$, novel PKCs such as PKC $-\delta,-\varepsilon,-\eta,-\theta$, and $-\mu$, and atypical PKCs such as PKC- $\lambda / 1$ for mouse/human, $-\zeta$ and $-v$. PKCs are activated through several pathways linked to phospholipase C (PLC), phospholipase $A_{2}$ $\left(\mathrm{PLA}_{2}\right.$ ), phospholipase D (PLD), and phosphatidylcholine-specific PLC [8-10]. PLC hydrolyzes phosphatidylinositol 4,5-bisphosphate into diacylglycerol and inositol 1,4,5-trisphosphate $\left(\mathrm{IP}_{3}\right)$, the latter activating $\mathrm{IP}_{3}$ receptors to release $\mathrm{Ca}^{2+}$ from intracellular calcium stores, and conventional PKCs are activated by diacylglycerol and $\mathrm{Ca}^{2+}[9,10]$. Phosphatidylcholinespecific PLC produces diacylglycerol by hydrolysis of phosphatidylcholine, thereby activating PKC [8]. Cis-unsaturated free fatty acids such as arachidonic, oleic, linoleic, linolenic, and docosahexaenoic acid, that are produced by $\mathrm{PLA}_{2}$-catalyzed hydrolysis of phosphatidylcholine, activate novel PKCs in a $\mathrm{Ca}^{2+}$-independent manner $[9,10]$. The free fatty acids, alternatively, are implicated in synergistic activation of conventional PKCs or sustained activation of conventional PKCs activated $[9,10]$.

In the present study, indomethacin activated PKC in PC-12 cells, and the activation was inhibited by knocking-down PKC- $\varepsilon$. Of PKC- $\alpha,-\beta \mathrm{I},-\beta \mathrm{II},-\gamma,-\delta,-\varepsilon,-1$, and $-\zeta$, indomethacin activated PKC- $\varepsilon$ alone in the absence of diacylglycerol, phosphatidylserine, and calcium under the cell-free conditions. In the indomethacin binding assay using a fluorescein-conjugated indomethacin, indomethacin directly bound to PKC- $\varepsilon$. Taken together, these results lead to a conclusion that indomethacin is capable of selectively activating PKC- $\varepsilon$ through its direct binding. This represents the novel indomethacin action, independently of COX inhibition.

In our earlier study, indomethacin potentiated $\alpha 7 \mathrm{ACh}$ receptor currents and facilitated hippocampal synaptic transmission in a PKC-dependent manner [6]. Of PKC isozymes PKC$\varepsilon$ is enriched in the presynaptic terminals and regulates neurotransmitter release [11]. $\alpha 7$ ACh receptors, on the other hand, are preferentially localized at presynaptic terminals in the brain and stimulates neurotransmitter release [12-15]. Indomethacin, accordingly, could enhance activity of presynaptic $\alpha 7$ ACh receptors by activating PKC- $\varepsilon$, causing an increase in presynaptic glutamate release, to facilitate hippocampal synaptic transmission.

In conclusion, the results of the present study show that indomethacin serves as a selective PKC- $\varepsilon$ activator through its direct binding.

\section{References}

1 Etminan M, Gill S, Samii A: Effect of nonsteroidal anti-inflammatory drugs on risk of Alzheimer's disease: systematic review and meta-analysis of observational studies. Br Med J 2003;327:128.

2 in t' Veld BA, Ruitenberg A, Hofman A, Launer LJ, van Duijn CM, Stijnen T, Breteler MM, Stricker B: Nonsteroidal antiinflammatory drugs and the risk of Alzheimer's disease. N Eng J Med 2001;345:15151521.

3 Szekely CA, Thorne JE, Zandi PP, Ek M, Messias E, Breitner JC, Goodman SN: Nonsteroidal anti-inflammatory drugs for the prevention of Alzheimer's disease: a systematic review. Neuroepidemiology 2004;23:159169. 
4 Townsend KP, Praticò D: Novel therapeutic opportunities for Alzheimer's disease: focus on nonsteroidal anti-inflammatory drugs. FASEB J 2005;19:1592-1601.

5 Kanno T, Yaguchi T, Nagata T, Shimizu T, Tanaka A, Nishizaki T: Indomethacin enhances learning and memory potential by interacting with CaMKII. J Cell Physiol 2012;227:919-926.

6 Kanno T, Yaguchi T, Nagata T, Nishizaki T: Indomethacin activates protein kinase C and potentiates $\alpha 7$ ACh receptor responses. Cell Physiol Biochem 2012;2012;29:189-196.

7 Shimizu T, Kanno T, Tanaka A, Nishizaki, T: $\alpha, \beta$-DCP-LA selectively activates PKC- $\varepsilon$ and stimulates neurotransmitter release with the highest potency among 4 diastereomers. Cell Physiol Biochem 2011;27:149-158.

$>8$ Isakov N: Activation of murine lymphocytes by exogenous phosphatidylethanolamine- and phosphatidylcholine-specific phospholipase C. Cell Immunol 1993;152:72-81.

-9 Nishizuka Y: Intracellular signaling by hydrolysis of phospholipids and activation of protein kinase C. Science 1992;258:607-614.

10 Nishizuka Y: Protein kinase C and lipid signaling for sustained cellular responses. FASEB J 1995;9:484-496.

11 Shirai Y, Adachi N, Saito N: Protein kinase Ce: function in neurons. FEBS J 2008;275:3988-3994.

12 Nishizaki T, Nomura T, Matsuyama S, Kondoh T, Fujimoto E, Yoshii M: Critical role of presynaptic nicotinic ACh receptor in the formation of long-term potentiation: implication of development of anti-dementia drug. Psychogeriatrics 2001;1:209-217.

13 Yamamoto S, Kanno T, Nagata T, Yaguchi T, Tanaka A, Nishizaki T: The linoleic acid derivative FR236924 facilitates hippocampal synaptic transmission by enhancing activity of presynaptic $\alpha 7$ acetylcholine receptors on the glutamatergic terminals. Neuroscience 2005;130:207-213.

14 Kanno T, Yaguchi T, Yamamoto S, Nagata T, Yamamoto H, Fujikawa H, Nishizaki T: Bidirectional regulations for glutamate and GABA release in the hippocampus by $\alpha 7$ and non- $\alpha 7$ ACh receptors. Biochem Biophys Res Commun 2005;338:742-747.

15 Kanno T, Yaguchi T, Yamamoto S, Yamamoto H, Fujikawa H, Nagata T, Tanaka A, Nishizaki T: 8-[2-(2-Pentylcyclopropylmethyl)-cyclopropyl]-octanoic acid stimulates GABA release from interneurons projecting to CA1 pyramidal neurons in the rat hippocampus via pre-synaptic $\alpha 7$ acetylcholine receptors. J Neurochem 2005;95:695-702. 